\title{
Pengaruh Konsep Diri dan Iklim Keluarga melalui Motivasi Berprestasi, Sikap, dan Kreativitas terhadap Hasil Belajar Matematika
}

\author{
Nurhidayah \\ Universitas Andi Djemma Palopo \\ Jl. Tandipau, Tomarundung, Wara Barat, Palopo, 91913, Sulawesi Selatan \\ E-mail: hidayah03@gmail.com
}

Article History:
Received: 03-12-2018; Received in revised form: 26-01-2019; Accepted: 04-02-2019;

Available online: 12-03-2019

\begin{abstract}
This is an Ex Post Facto research which aimed to investigate the influence of self concept and family climate through achievement motivation, attitude, and creativity toward mathematics learning outcomes of XIth grade science student of public senior high school in Palopo. Population of this research consisted of all XI grade science students of public senior high schools in Palopo. Sampling was taken by multi-stage random sampling. Data were taken by employing six instruments, namely questionnaire of self concept, family climate, achievement motivation, attitudes to mathematics, mathematics learning creativity, and mathematics learning achievement test. It was analyzed by using SEM analysis (Structural Equation Modeling) by software AMOS 20 and also by Sobel test to examine the indirect influence and signification through intervening. The results of the research showed that students' mathematics learning outcomes was fair category by the mean score of 68 of ideal 100. Whereas self concept with persentage $62.2 \%$, family climate $72.6 \%$, attitudes in mathematics $71 \%$, achievement motivation $70.9 \%$, creativity and learning mathematics $61 \%$ from the expected score 100\%. Analysis of measurement model explained that all the construct were well explained by the dimensions, and for Goodness of Fit test based on the score of significant probability, RMSEA, GFI, AGFI, CMIN / DF, TLI, and CFI showed that the structural equation model have fulfilled the condition of a good model. Hypothesis test indicated that significant achievement motivation was influenced by self concept and family climate, attitudes to mathematics was significantly influenced by the concept of self, family climate and achievement motivation, creativity was significantly influenced by attitude in mathematics, but not significantly influenced by the self concept and family climate. Moreover, mathematics learning outcomes was significantly influenced directly by self concept, family climate, and mathematics learning creativity.
\end{abstract}

Keywords: Self Concept; Family Climate; Achievement Motivation; Attitudes to Mathematics; Mathematics Learning Creativity; and Mathematics Learning Achievement.

\begin{abstract}
Abstrak
Penelitian ini merupakan penelitian ex-post facto yang bertujuan untuk meneliti pengaruh konsep diri dan iklim keluarga melalui motivasi berprestasi, sikap, dan kreativitas terhadap hasil belajar matematika siswa kelas XI SMA Negeri di Kota Palopo. Populasi penelitian ini adalah semua siswa IPA kelas XI SMA Negeri di Palopo. Pengambilan sampel dilakukan dengan multi-stage random sampling. Data diambil dengan menggunakan enam instrumen, yaitu angket konsep diri, iklim keluarga, motivasi berprestasi, sikap matematika, kreativitas
\end{abstract}


belajar matematika, dan tes prestasi belajar matematika. Data kemudian dianalisis dengan menggunakan analisis SEM (Structural Equation Modeling) dengan menggunakan bantuan software AMOS 20 dan juga dengan menggunakan tes Sobel untuk menguji pengaruh tidak langsung dan signifikansi melalui Variabel Perantara (Intervening). Hasil penelitian menunjukkan bahwa hasil belajar matematika berada pada kategori sedang dengan nilai rata-rata dari 68 dari yang ideal 100. Sedangkan konsep diri dengan presentase 62,2\%, iklim keluarga 72,6\%, sikap dalam matematika 71\%, motivasi berprestasi 70,9\%, kreativitas dan belajar matematika 61\% dari nilai yang diharapkan 100\%. Analisis pengukuran model menjelaskan bahwa semua konstruk dijelaskan dengan baik oleh setiap dimensi, dan untuk uji goodness of fit berdasarkan skor signifikansi probabilitas, RMSEA, GFI, AGFI, CMIN / DF, TLI, dan CFI menunjukkan bahwa model persamaan struktural telah memenuhi syarat sebagai model yang baik. Uji hipotesis menunjukkan motivasi berprestasi signifikan dipengaruhi oleh konsep diri dan iklim keluarga, sikap terhadap matematika dipengaruhi oleh konsep diri, iklim keluarga dan motivasi berprestasi, kreativitas dipengaruhi oleh sikap pada matematika, tetapi tidak dipengaruhi secara signifikan oleh konsep diri dan iklim keluarga. Selain itu, hasil belajar matematika secara signifikan dipengaruhi secara langsung oleh konsep diri, iklim keluarga, dan kreativitas belajar matematika.

Kata Kunci: Konsep Diri; Iklim Keluarga; Motivasi Berprestasi; Sikap Matematika; Kreativitas Belajar Matematika; Prestasi Belajar Matematika.

\section{Pendahuluan}

Pendidikan merupakan sarana bagi pengembangan kualitas sumber daya manusia di suatu negara. Melalui pendidikan, kualitas hidup dapat dikembangkan baik secara individu maupun dalam kehidupan berbangsa. Pendidikan juga sudah diyakini sebagai parameter keberhasilan dan kejayaan suatu negara. Sehingga wajar jika semua negara berlomba-lomba memperbaiki sistem pendidikannya termasuk di Indonesia.

Dalam meningkatkan kualitas sumber daya manusia diperlukan sikap kemandirian dan kemampuan berpikir logis. Hal ini tidak terlepas dari matematika yang sesai dengan tujuan pendidikan dasar dan menengah yaitu menekankan pada penataan nalar dan pembentukan kepribadian siswa agar dapat menerapkan atau menggunakan matematika dalam kehidupannya. Dengan pentingnya pentingnya pembelajaran matematika maka dibutuhkan pula kualitas hasil belajar matematika yang baik. Namun, yang menjadi permasalahan adalah sampai sekarang kualitas hasil belajar matematika masih rendah dibandingkan pelajaran lain, baik dalam skala nasional maupun dalam skala internasional.

Hasil survey yang dilakukan oleh Trend Mathematics and Science Study (TIMSS), melaporkan bahwa kemampuan matematika siswa SMP kita berada di urutan ke-34 dari 38 negara. Begitupula hasil survey oleh International Association for the Evaluation of Education (IEA) bahwa Indonesia juga berada di urutan ke-34 dari 38 negara berdasarkan hasil belajar matematika siswa sekolah menengah. Sedangkan menurut hasil penelitian PISA (Programme for International Student Assesment), diantara 41 peserta 
indonesia berada pada peringkat ke-39 untuk literasi membaca dan matematika. Walaupun hal ini merupakan nilai nilai rata-rata keseluruhan penduduk yang ada di Indonesia, namun setidaknya data ini telah menjadi barometer tentang kualitas pendidikan di negara ini.

Hilgard dan Bower dalam Purwanto (2011:84), dalam buku Theories of Learning (1975) mengemukakan, belajar berhubungan dengan perubahan tingkah laku seseorang terhadap situasi tertentu yang disebabkan oleh pengalamannya yang berulang-ulang dalam situasi itu, dimana perubahan tingkah laku itu tidak dapat dijelaskan atau dasar kecenderungan respon pembawaan, kematangan, atau keadaaan-keadaan sesaat seseorang, misalnya kelehan, pengaruh obat, dsb ${ }^{1}$. Sedangkan Gagne pada buku The Conditions of Learning (1977) menyatakan bahwa belajar terjadi apabila suatu situasi stimulus bersama dengan isi ingatan mempengaruhi siswa sedemikian rupa sehingga perbuatannya berubah dari waktu sebelum ia mengalami situasi itu ke waktu sesudah mengalami situasi tersebut ${ }^{2}$. Bloom (dalam Thompson, 2008) mendefinisikan hasil belajar adalah sebagai hasil perubahan tingkah laku yang meliputi tiga ranah yaitu ranah kognitif, afektif, dan psikomotorik ${ }^{3}$.

Kreativitas merupakan kemampuan untuk menghasilkan produk baru 4 . Sedangkan menurut Munandar, mendefenisikan kreativitas sebagai "creativity is a process that manifest itself in fluency, in flexibility as well in originality of thinking". Kreativitas adalah sebuah proses yang digunakan oleh seseorang dengan fasih, fleksibel sebagai suatu proses berpikir yang sebenarnya ${ }^{5}$.

Singh memberikan defenisi "mathematical creativity as the process of formulating hypotheses concerning cause and effect in a mathematical situation, testing and retesting these hypotheses and making modifications and finally communicating the result"6. Maksudnya adalah kreativitas matematika merupakan sebuah proses untuk membangun sebuah hipotesis mengenai sebab akibat dalam situasi matematika dan menguji hipotesis tersebut dan membuat modifikasi dan pada akhirnya mengkomunikasikan hasil yang diperoleh. Dalam hal ini Singh mendefenisikan kreativitas 84.

1 Ngalim Purwanto, Psikologi Pendidikan (Bandung: PT. Remaja Rosdakarya, 2011),

2 Purwanto, Psikologi Pendidikan.

3 Tony Thompson, "Mathematics Teachers' Interpretation of Higher-Order Thinking in Bloom's Taxonomy," International Electronic Journal of Mathematics Education 3, no. 2 (August 8, 2008): 96-109.

4 Robert J. Sternberg, ed., Handbook of Creativity, 1 edition (Cambridge, U.K. ; New York: Cambridge University Press, 1998).

${ }^{5}$ Munandar Utami, Pengembangan Kreativitas Anak Berbakat (Jakarta: Rineka Cipta, 2009).

${ }^{6}$ Savas Akgul and Nihat Gurel Kahveci, "A Study on the Development of a Mathematics Creativity Scale," Eurasian Journal of Educational Research, 2016, https://eric.ed.gov/?id=EJ1097919. 
matematika langsung pada aspek proses yang terjadi dalam sebuah kreativitas. Menurut Guilford sifat dari sebuah kreativitas yaitu kelancaran (fluency), keluwesan (flexibility), keaslian (originality), penguraian (elaboration), dan perumusan kembali (redefinition).

Sax mengemukakan bahwa "an attitude was defined as a preference along a dimension of favorableness to unfavoravleness to a particular group, institution, concept, or object"7. Artinya, sikap adalah karakteristik dari seseorang yang menggambarkan perasaan positif dan negatif mereka terhadap objek, situasi, institusi, seseorang atau ide tertentu. Warren menyatakan bahwa "sikap adalah daya mental yang khusus untuk menanggapi berbagai pengalaman yang dapat mengubah pengalaman".

Hannula (2002) memberikan defenisi sikap terhadap matematika sebagai pandangan atau kecenderungan seseorang terhadap matematika. Pandangan atau kecenderungan ini akan dapat dilihat dari tanggapan seseorang terhadap matematika baik tanggapan dalam hal emosi, reaksi, harapan, dan nilai ${ }^{8}$. Sedangkan menurut Leonard (2008), sikap terhadap matematika adalah perasaan terhadap matematika, kesediaan untuk mempelajari, dan kesadaran terhadap manfaat matematika ${ }^{9}$.

Vroom mengatakan bahwa motivasi mengacu kepada suatu proses yang mempengaruhi pilihan-pilihan individu terhadap bermacam-macam bentuk kegiatan yang dikehendaki ${ }^{10}$. Motivasi berprestasi adalah dorongan yang menggerakkan seseorang untuk melakukan keinginan yang dilandasi adanya tujuan mencapai prestasi yang baik ${ }^{11}$. Dengan demikian motivasi berprestasi dapat mendorong usaha-usaha pencapaian hasil belajar yang maksimal termasuk dalam bidang Matematika.

Keluarga merupakan lingkungan pertama dalam kehidupan anak yang mula-mula memberikan pengaruh yang mendala bagi perkembangan dan kehidupan anak. Keluarga memberikan dasar tingkah laku, watak, moral, dan pendidikan kepada anak. Dari keluargalah seorang anak mendapat pengaruh yang pertama dalam pertumbuhan biologis maupun perkembangan jiwanya atau pribadinya. Keluarga merupakan tempat memperoleh latihan-latihan dasar dalam mengembangkan sikap sosial yang baik dan kebiasaan-kebiasaan

7 Gilbert Sax, Principles of Educational Measurement and Evaluation (Wadsworth Publishing Company, 1973).

8 Markku Hannula, "Attitude Toward Mathematics: Emotions, Expectations and Values," Educational Studies in Mathematics 49 (January 1, 2002): 25-46, https://doi.org/10.1023/A:1016048823497.

${ }^{9}$ Leonard and Supardi US, "Pengaruh Konsep Diri, Sikap Siswa Pada Matematika, Dan Kecemasan Siswa Terhadap Hasil Belajar Matematika," Jurnal Cakrawala Pendidikan 3, no. 3 (2010), https://doi.org/10.21831/cp.v3i3.362.

10 Purwanto, Psikologi Pendidikan, 72.

11 A. M. Sardiman, Psikologi Praktis: Anak, Remaja, Dan Keluarga (Jakarta: Rajawali Pers, 1987). 
berperilaku di dalam keluarga terbentuk pola penyesuaian sebagai dasar hubungan sosial dan nteraksi sosial yang lebih luas ${ }^{12}$.

Ada beberapa fungsi keluarga yaitu fungsi edukasi, sosialisasi, proteksi, afeksi, religius, ekonomi, rekreasi dan biologis ${ }^{13}$. Iklim yang dimiliki oleh suatu keluarga akan mempengaruhi perkembangan pribadi anak, dimana penciptaan dan penangkapan iklim keluarga dapat dimanfaatkan bagi pelaksanaan pendidikan dalam keluarga. Iklim keluarga adalah suasana kehidupan dalam keluarga yang dirasakan dihayati oleh sekelompok orang yang berada dan menghirup suasana tersebut ${ }^{14}$. Iklim tersebut menciptakan kondisi bagi tingkah laku anggota keluarganya. Iklim keluarga yang dimaksud dalam hal ini adalah suasan psikologis yang ditanggapi dan dirasakan oleh anak serta berpengaruh terhadap kecenderungan pola perilaku anggota keluarga terutama anak.

Lussier menyatakan "your self-concept is your overall attitude about yourself $f^{\prime 15}$. Artinya konsep diri adalah keseluruhan sikap tentang diri sendiri. Lussier menambahkan bahwa "self-concept is your perception of yourself, which may not be the way others perceive you". Konsep diri adalah persepsi seseorang tentang dirinya sendiri, yang mana tidak ada cara yang lain untuk mempersepsikan dirinya. Sehingga, individu memikirkan dan merasakan tentang dirinya sendiri termasuk keyakinan dan sikapnya mengenai dirinya sendiri.

Konsep diri matematika yang positif memberikan pengaruh teradap konsep diri skala sikap kejujuran dan percaya diri. Konsep diri matematika juga berhubungan erat dengan konsep diri akademis umumnya. Siswa yang memiliki konsep diri akademis matematika yang baik akan memiliki konsep diri akademis yang baik pula. Oleh karena itu, pada penelitian ini, konsep diri dibatasi pada tiga dimensi yaitu kejujuran dan kepercayaan, akademis umum dan akademis matematika.

Berdasarkan hal tersebut, perlu dilakukan pengkajian lebih lanjut mengenai faktor yang mempengaruhi hasil belajar matematika siswa. Mengingat cukup banyak faktor yang mempengaruhi hasil belajar matematika siswa, maka maka penulis hanya mengambil lima variabel yang berpengaruh terhadap hasil belajar matematika, baik yang berasal dari faktor internal dan eksternal yaitu konsep diri, iklim keluarga, motivasi berprestasi, sikap terhadap matematika dan kreativitas belajar matematika .

12 Singgih Gunarsa, Psikologi Praktis: Anak, Remaja, Dan Keluarga (Jakarta: Gunung Mulia, 2004).

${ }^{13}$ Soelaeman MI, Perkembangan Anak Dan Remaja (Bandung: PT. Remaja Rosdakarya, 1999).

$14 \mathrm{MI}$.

15 Leonard and US, "Pengaruh Konsep Diri, Sikap Siswa Pada Matematika, Dan Kecemasan Siswa Terhadap Hasil Belajar Matematika.” 


\section{Metode}

Penelitian ini menggunakan jenis penelitian kuantitatif yaitu ex-post facto yang bersifat korelasional. Instrumen yang digunakan adalah angket yang terdiri dari angket konsep diri, iklim keluarga, sikap terhadap matematika, motivasi berprestasi, dan kreativitas belajar matematika serta instrumen berupa tes hasil belajar matematika. Populasi dalam penelitian ini adalah seluruh siswa kelas XI jurusan IPA sekolah menengah negeri di kota palopo. Adapun sampelnya terdiri dari empat sekolah yang dipilih secara multi stage random sampling yaitu SMAN 1 palopo, SMAN 3 Palopo, SMAN 6 Palopo, dan MAN Palopo. Data yang dikumpul dianalisis dengan menggunakan dua teknik yaitu pertama dengan analisis deskriptif untuk memperoleh gambaran data menggunakan software Ms. Excel dan SPSS, kedua dengan analisis inferensial yang menggunakan bantuan software AMOS 20 dan Sobel Test.

\section{Hasil Angket dan Tes Hasil Belajar}

Analisis deskripsi setiap variabel dihitung dengan membagi nilai yang diperoleh dengan skor ideal tiap variabel. Konsep diri memperoleh nilai sebesar $62 \%$ dari skor yang diharapkan yaitu $100 \%$ memiliki konsep diri yang baik. Selain itu lebih rinci untuk setiap item yang terdiri dari 20 butir, yang memperoleh nilai tertinggi adalah item nomor 3 mengenai nilai pada setiap mata pelajaran. Sedangkan untuk deskripsi berdasarkan 3 dimensi yang membangun konsep diri yaitu kejujuran dan kepercayaan, akademis matematik, dan akademis umum, yang memiliki nilai tertinggi adalah pada dimensi akademis umum.

Iklim keluarga dengan skor ideal 9.874 diperoleh nilai sebesar 0,726 atau sebesar $73 \%$ dari skor yang diharapkan yaitu $100 \%$. Dengan item pernyataan tertinggi mengenai arti penting keluarga dan yang paling rendah mengenai pemenuhan kebutuhan akademik. Sedangkan berdasarkan 3 dimensi yang membangun iklim keluarga yaitu hubungan keluarga, sistem pemeliharaan lingkungan, dan pertumbuhan pribadi, maka yang memperoleh skor tertinggi adalah pada dimensi hubungan keluarga yaitu sebesar $83,16 \%$.

Motivasi berprestasi dengan skor ideal 9.645 diperoleh nilai sebesar 0,709 atau $70,09 \%$ dari nilai yang diharapkan yaitu $100 \%$ memiliki motivasi berprestasi yang tinggi. Analisis untuk tiap item pernyataan yang terdiri dari 21 butir, yang memperoleh nilai tertinggi adalah pada item mengenai membentuk diri menjadi lebih baik dan yang paling rendah adalah pada item mengenai penggunaan waktu di malam hari untuk belajar. Sedangkan berdasarkan 5 dimensi yang membangun variabel ini, yang memiliki nilai tertinggi adalah dimensi berambisi dan yang paling rendah adalah tekun berusaha. 
Sikap terhadap matematika dengan skor ideal 16.338, diperoleh nilai sebesar 0,71 atau 71\% dari nilai yang diharapkan yaitu 100\% memiliki sikap yang baik terhadap matematika. analisis deskripsi untuk setiap item pernyataan diperoleh bahwa dari 27 item pernyataan, yang memperoleh nilai tertinggi adalah pada item mengenai bekerj dengan baik saat ulangan dan yang paling rendah adalah mengenai gugup saat mengerjakan soal matematika. sedangkan berdasarkan 3 dimensi yang membangun variabel ini yaitu dimensi nilai, reaksi emosi dan harapan, dimensi dengan nilai tertinggi adalah harapan dengan nilai 76,1\% dari nilai yang diharapkan.

Kreativitas belajar matematika dengan skor ideal 12.430, diperoleh nilai sebesar $0,61 \%$ atau $61 \%$ dari nilai yang diharapkan yaitu 100\% memiliki kreativitas belajar yang tinggi. Adapun analisis untuk setiap item pernyataan yang terdiri dari 24 butir, yang memperoleh nilai tertinggi yaitu pada item mengenai berusaha memikirkan cara penyelesaian soal dan yang paling rendah adalah pernyataan mengenai mampu belajar sendiri tanpa dibimbing oleh guru. Sedangkan analisis berdasarkan dimensi dari 5 dimensi yang membangun variabel kreativitas yaitu keluwesan, keaslian, elaborasi, kelancaran, dan perumusan kembali, yang memiliki nilai tertinggi adalah dimensi elaborasi dan paling rendah pada dimensi kelancaran.

Hasil belajar matematika berdasarkan tes yang diberikan kepada siswa menunjukkan nilai mean atau rata-rata yang diperoleh sebesar 68,48\% dengan nilai tertinggi sebesar 100 dan nilai terendah 33. Nilai yang diperoleh kemudian dimasukkan dalam tabel distribusi frekuensi berdasarkan 5 kategori sangat rendah, rendah, sedang, tinggi, dan sangat tinggi. Berdasarkan tebael tersebut dapat disimpulkan bahwa hasil belajar matematika siswa kelas XI jurusan IPA sekolah menengah negeri di kota palopo berada pada kategori sedang dengan persentase sebesar 32\%.

Analisis inferensial ini menggunakan structural equation modelling (SEM). Sebelum dilakukan analisis SEM, terlebih dahulu dilakukan uji asumsi sebagai prasyarat sebelum melakukan analisis SEM yaitu uji kecukupan sampel, normalitas, dan outlier. Setelah ketiga asumsi terpenuhi, dilakukan uji kesesuaian model (goodness of fit) dengan memperhatikan nilai significant probability $(0,463>0,05)$, RMSEA $(0,006<0,08)$, GFI $(0,931>0,90)$, AGFI $(0,893>0,75)$, CMIN/DF $(1,006<2.00)$, TLI $(0,999>0,95)$, dan CFI $(0,999>$ $0,95)$. Hasil goodness of fit mengindikasikan bahwa model yang diajukan dalam penelitian ini dapat diterima untuk selanjutnya dilakukan uji kesahihan konvergen (convergen validity) untuk menguji kesahihan dimensi untuk setiap variabel, apakah tiap variabel signifikan dibangun oleh dimensinya. Hasil pengujian kesahihan konvergen terlihat bahwa setiap variabel signifikan dibangun oleh dimensinya. Oleh karena telah memenuhi keseluruhan uji asumsi, maka pengujian hipotesis dapat dilakukan. 


\section{Pengaruh Konsep Diri, Iklim Keluarga, terhadap Motivasi Berprestasi}

Motivasi berprestasi signifikan dipengaruhi secara langsung oleh kedua variabel tersebut. Hal ini telihat dari nilai p-value yang diperoleh. Nilai koefisien determinasi $\left(\mathrm{R}^{2}\right)$ sebagai besaran untuk melihat seberapa besar total konstruk motivasi berprestasi yang dipengaruhi oleh konsep diri, iklim keluarga. Adapun nilai koefisien determinasi yang diperoleh sebesar 86,8\%, yang berarti sebesar $86,8 \%$ motivasi berprestasi dipengaruhi oleh kedua variabel tersebut tanpa mempertimbangkan variabel lain.

Hasil penelitian ini sejalan dengan yang dilakukan oleh Satriani bahwa konsep diri berpengaruh positif dan siginifikan terhadap motivasi berprestasi ${ }^{16}$. Lebih khusus Middleton \& Spanias mengemukakan bahwa motivasi berprestasi memiki kaitan erat dengan konsep diri ${ }^{17}$.

\section{Pengaruh Konsep Diri, Iklim Keluarga, dan Motivasi Berprestasi terhadap Sikap pada Matematika}

Berdasarkan hasil analisis diperoleh informasi bahwa konsep diri, iklim keluarga, dan motivasi berprestasi mempunyai pengaruh langsung positif dan signifikan terhadap sikap pada matematika. Hal ini dapat dilihat dari nilai signifikansinya. Konsep diri memiliki nilai pengaruh sebesar 43,2\%, iklim keluarga sebesar 21,1\%, motivasi berprestasi sebesar 40,2\%. Dengan nilai koefisien determinasi $\left(\mathrm{r}^{2}\right)$ sebesar $75,3 \%$.

Hasil yang diperoleh dari penelitian ini sejalan dengan teori dan penelitian yang dikemukakan oleh Leonard yang menyatakan bahwa ada pengaruh positif dan siginifikan antara konsep diri siswa terhadap sikap siswa pada Matematika ${ }^{18}$. Dengan kata lain, siswa yang memiliki kepercayaan diri dan persepsi serta cara pandang yang positif tentang dirinya sendiri akan mampu memperbaiki sikapnya pada matematika.

\section{Pengaruh Konsep Diri, Iklim Keluarga, Motivasi Berprestasi, dan Sikap pada Matematika terhadap Kreativitas Belajar Matematika}

Hasil analisis mengenai pengaruh terhadap kreativitas, diperoleh informasi bahwa dari ketiga variabel yang mempengaruhi kreativitas, terdapat dua variabel yang signifikan teruji kebenarannya mempengaruhi

16 Satriani Satriani, "Pengaruh Iklim Kelas Dan Konsep Diri Terhadap Motivasi Berprestasi Dan Hasil Belajar Fisika Peserta Didik Kelas XI IPA SMA Negeri 1 Kahu” (masters, Universitas Negeri Makassar, 2016), http://eprints.unm.ac.id/3759/.

17 James A. Middleton and Photini A. Spanias, "Motivation for Achievement in Mathematics: Findings, Generalizations, and Criticisms of the Research," Journal for Research in Mathematics Education 30, no. 1 (1999): 65-88, https://doi.org/10.2307/749630.

18 Leonard and US, "Pengaruh Konsep Diri, Sikap Siswa Pada Matematika, Dan Kecemasan Siswa Terhadap Hasil Belajar Matematika,” 350. 
kreativitas yaitu konsep diri dan iklim keluarga, sedangkan sikap signifikan mempengaruhi kreativitas. Namun dalam hipotesis tidak langsung, konsep diri dan iklim keluarga signifikan mempengaruhi kreativitas baik melalui motivasi berprestasi ataupun sikap. Sejalan dengan ini, motivasi berprestasi dalam kaitannya dengan pengaruh tidak langsung, variabel ini signifikan teruji mempengaruhi kreativitas. Adapun nilai koefisien determinasi $\left(r^{2}\right)$ sebesar $59,3 \%$.

Hasil ini sejalan dengan penelitian yang dilakukan oleh Johny (2008) yang mengkaji tentang pengaruh beberapa faktor terhadap kreativitas belajar matematika. Dari penelitian tersebut disimpulkan bahwa konsep diri dan sikap pada matematika signifikan mempengaruhi kreativitas belajar matematika. Selain itu, dikatakan bahwa untuk meningkatkan kreativitas belajar matematika siswa maka perlu ditingkatkan konsep diri siswa dan mengubah sikapnya terhadap matematika, disini dikatakan yang paling berperan adalah guru ${ }^{19}$.

\section{Pengaruh Konsep Diri, Iklim Keluarga, Sikap pada Matematika, Motivasi Berprestasi, dan Kreativitas Belajar Matematika terhadap Hasil Belajar Matematika Siswa}

Konsep diri, iklim keluarga dan kreativitas belajar matematika berpengaruh positif secara langsung dan signifikan terhadap hasil belajar matematika. Variabel lainnya tidak berpengaruh secara signifikan. Hal ini dikarenakan pengaruh variabel intervenning yang dilalui terhadap hasil belajar sebagai variabel endogen tidak signifikan. Hal ini mengindikasikan bahwa selain variabel motivasi dan sikap, masih terdapat faktor lain yang menjadi perantara antara kedua variabel ini dengan hasil belajar yang tidak diteliti oleh penulis, hal ini dikarenakan tidak mutlak siswa dengan motivasi berprestasi yang tinggi dan sikap yang baik akan memperoleh hasil belajar yang baik pula. Namun, masih ada faktor lain yang berfungsi sebagai penyaring yang dapat mempengaruhi baik atau tidaknya hasil belajar matematika siswa. Adapun koefisien determinasi yang diperoleh adalah $48,1 \%$.

Hasil analisis ini sesuai dengan teori yang telah dipaparkan sebelumnya bahwa hasil belajar dapat dipengaruhi oleh faktor internal, faktor eksternal, dan pendekatan belajar ${ }^{20}$. Faktor internal meliputi faktor fisik, afektif, kognitif, sedangkan faktor eksternal misalnya keluarga, sekolah, teman, masyarakat, dan pendektan pembelajaran meliputi metode atau model pembelajaran yang

${ }^{19}$ S Johny, "Effect of Some Environmental Factors on Mathematical Creativity of Secondary School Students of Kerla (India)" (Proceedings of the 11th Congress on Mathematical Education, Mexico, 2008).

${ }^{20}$ Muhibbin Syah, Psikologi Pendidikan (Bandung: PT. Remaja Rosdakarya, 2011). 
digunakan. Hal ini juga dikemukan oleh Purwanto yang membagi faktor tesebut menjadi dua bagian yaitu internal dan eksternal ${ }^{21}$. Secara spesifik juga sejalan dengan yang dikemukakan oleh Slameto bahwa hasil belajar matematika dipengaruhi oleh faktor internal yang meliputi faktor kognitif dan afektif seperti persepsi, kreativitas, motivasi, konsep diri, dan sikap. Sedangkan faktor eksternal berupa keluarga dan sekolah ${ }^{22}$.

Rangkuman pengaruh langsung, tidak langsung, dan pengaruh total dari masing-masing variabel dapat dilihat pada Tabel 1 berikut:

Tabel 1. Gambaran Pengaruh Satu Variabel terhadap Variabel Lainnya

\begin{tabular}{|c|c|c|c|c|c|c|c|c|}
\hline \multirow{3}{*}{$\begin{array}{c}\text { Pengaruh } \\
\text { Variabel }\end{array}$} & \multicolumn{8}{|c|}{ Pengaruh Kausal } \\
\hline & \multirow[b]{2}{*}{ Langsung } & \multicolumn{6}{|c|}{ Tidak Langsung } & \multirow[b]{2}{*}{ Total } \\
\hline & & $\begin{array}{c}\text { Melalui } \\
\mathrm{Y}_{1}\end{array}$ & $\begin{array}{c}\text { Melalui } \\
\mathrm{Y}_{2}\end{array}$ & $\begin{array}{c}\text { Melalui } \\
\mathrm{Y}_{3}\end{array}$ & $\begin{array}{c}\text { Melalui } \\
\mathrm{Y}_{1} \text { dan } \\
\mathrm{Y}_{2}\end{array}$ & $\begin{array}{c}\text { Melalui } \\
\mathrm{Y}_{2} \text { dan } \\
\mathrm{Y}_{3}\end{array}$ & $\begin{array}{c}\text { Melalui } \\
\mathrm{Y}_{1}, \mathrm{Y}_{2} \\
\text { dan } \mathrm{Y}_{3}\end{array}$ & \\
\hline $\mathrm{X}_{1}$ terhadap $\mathrm{Y}_{1}$ & 0,853 & - & - & - & - & - & - & 0,853 \\
\hline $\mathrm{X}_{2}$ terhadap $\mathrm{Y}_{1}$ & 0,374 & - & - & - & - & - & - & 0,374 \\
\hline $\mathrm{X}_{1}$ terhadap $\mathrm{Y}_{2}$ & 0,432 & 0,343 & - & - & - & - & - & 0,775 \\
\hline $\mathrm{X}_{2}$ terhadap $\mathrm{Y}_{2}$ & 0,211 & 0,150 & - & - & - & - & - & 0,361 \\
\hline $\mathrm{X}_{1}$ terhadap $\mathrm{Y}_{3}$ & 0,227 & - & 0,261 & - & 0,204 & - & - & 0,692 \\
\hline $\mathrm{X}_{2}$ terhadap $\mathrm{Y}_{3}$ & $-0,113$ & - & 0,127 & - & 0,091 & - & - & 0,105 \\
\hline $\mathrm{X}_{1}$ terhadap $\mathrm{Y}$ & 0,423 & 0,105 & $-0,041$ & 0,054 & $-0,032$ & 0,062 & 0,049 & 0,621 \\
\hline $\mathrm{X}_{2}$ terhadap $\mathrm{Y}$ & 0,226 & 0,046 & $-0,020$ & $-0,027$ & $-0,014$ & 0,030 & 0,022 & 0,263 \\
\hline$Y_{1}$ terhadap $Y_{2}$ & 0,402 & - & - & - & - & - & - & 0,402 \\
\hline $\mathrm{Y}_{1}$ terhadap $\mathrm{Y}_{3}$ & - & - & 0,243 & - & - & - & - & 0,243 \\
\hline $\mathrm{Y}_{2}$ terhadap $\mathrm{Y}_{3}$ & 0,604 & - & - & - & - & - & - & 0,604 \\
\hline $\mathrm{Y}_{1}$ terhadap $\mathrm{Y}$ & 0,123 & - & $-0,038$ & - & - & 0,058 & - & 0,143 \\
\hline $\mathrm{Y}_{2}$ terhadap $\mathrm{Y}$ & $-0,095$ & - & - & 0,144 & - & - & - & 0,049 \\
\hline $\mathrm{Y}_{3}$ terhadap $\mathrm{Y}$ & 0,239 & - & - & - & - & - & - & 0,239 \\
\hline
\end{tabular}

Berdasarkan hasil penelitian ini dapat disimpulkan bahwa hasil belajar matematika tidaklah dipengaruhi oleh satu faktor saja. Bahkan tidak hanya dipengaruhi oleh faktor kecerdasan saja seperti yang banyak dipersepsikan oleh orang. Namun, hasil belajar matematika merupakan hasil dari berbagai pengaruh kompleks yang bersumber banyak faktor yang saling berhubungan satu dengan yang lain. Adapun keterbatasan dalam penelitian ini adalah keterbatasan waktu penelitian dan pengisian angket. Responden penelitian masih terbilang sedikit dari jumlah sampel yang biasa digunakan untuk analisis SEM. Walaupun sudah dianggap memadai, tetapi alangkah lebih bagusnya apabila jumlah respondennya lebih banyak, keterbatasan referensi dan teori yang digunakan atau yang dijadikan acuan, baik referensi buku, jurnal atau penelitian yang relevan dengan ide penelitian, serta instrumen yang digunakan yang berupa angket, merupakan hasil dari asumsi siswa. Oleh karena itu hasil dari angket tergantung dari subjektifitas individu dalam

21 Purwanto, Psikologi Pendidikan.

22 Slameto, Belajar Dan Faktor Yang Mempengaruhinya (Jakarta: Rineka Cipta, 2010). 
menjawab, dan asumsi itu tidak selalu sesuai dengan fakta. Dalam hal ini, kejujuran menilai diri sendiri juga mempunyai peranan yang penting.

\section{Penutup}

\section{Simpulan}

Hasil analisis deskriptif menunjukkan bahwa hasil belajar Matematika siswa kelas XI jurusan IPA SMA Negeri di kota Palopo tergolong dalam kategori sedang (dari lima kategori: sangat rendah, rendah, sedang, tinggi, dan sangat tinggi). Keseluruhan variabel yang diukur dengan menggunakan angket yaitu konsep diri, iklim keluarga, motivasi berprestasi, sikap dan kreativitas, signifikan dibangun oleh dimensinya masing-masing. Adapun model secara keseluruhan, berdasarkan kriteria Goodness of fit, dapat disimpulkan bahwa model telah fit dan dapat digunakan untuk pengujian hipotesis.

Uji hipotesis menunjukkan bahwa motivasi berprestasi signifikan dipengaruhi oleh konsep diri dan iklim keluarga, sikap terhadap matematika dipengaruhi oleh konsep diri, iklim keluarga dan motivasi berprestasi, kreativitas sangat dipengaruhi oleh sikap pada matematika, tetapi tidak dipengaruhi secara signifikan oleh konsep diri dan iklim keluarga. Selain itu, hasil belajar matematika secara signifikan dipengaruhi secara langsung oleh konsep diri, iklim keluarga, dan kreativitas belajar matematika.

Saran

Dalam pembelajaran matematika, diharapkan agar guru dan orang tua memperhatikan kebutuhan dan kendala siswa. Faktor yang mempengaruhi hasil belajar siswa baik yang berupa faktor internal yaitu faktor afektif maupun kognitif serta faktor eksternal berupa lingkungan harus diperhatikan. Karena dengan memperhatikan dan memperbaiki faktor tersebut dapat mempengaruhi hasil belajar siswa. Selain itu, Peneliti lain yang ingin melakukan penelitian yang sejalan dengan penelitian ini, sebaiknya menggunakan sampel yang lebih besar dan proporsi faktor afektif dan kognitif bisa diseimbangkan dan juga variabel kognitif akan lebih baik jika dilakukan dengan observasi secara langsung.

\section{Daftar Pustaka}

Akgul, Savas, and Nihat Gurel Kahveci. "A Study on the Development of a Mathematics Creativity Scale." Eurasian Journal of Educational Research, 2016. https://eric.ed.gov/?id=EJ1097919.

Gunarsa, Singgih. Psikologi Praktis: Anak, Remaja, Dan Keluarga. Jakarta: Gunung Mulia, 2004.

Hannula, Markku. "Attitude Toward Mathematics: Emotions, Expectations and Values." Educational Studies in Mathematics 49 (January 1, 2002): 25-46. https://doi.org/10.1023/A:1016048823497. 
Johny, S. "Effect of Some Environmental Factors on Mathematical Creativity of Secondary School Students of Kerla (India)." Mexico, 2008.

Leonard, and Supardi US. "Pengaruh Konsep Diri, Sikap Siswa Pada Matematika, Dan Kecemasan Siswa Terhadap Hasil Belajar Matematika." Jurnal Cakrawala Pendidikan 3, no. 3 (2010). https://doi.org/10.21831/cp.v3i3.362.

MI, Soelaeman. Perkembangan Anak Dan Remaja. Bandung: PT. Remaja Rosdakarya, 1999.

Middleton, James A., and Photini A. Spanias. "Motivation for Achievement in Mathematics: Findings, Generalizations, and Criticisms of the Research." Journal for Research in Mathematics Education 30, no. 1 (1999): 65-88. https://doi.org/10.2307/749630.

Purwanto, Ngalim. Psikologi Pendidikan. Bandung: PT. Remaja Rosdakarya, 2011.

Sardiman, A. M. Psikologi Praktis: Anak, Remaja, Dan Keluarga. Jakarta: Rajawali Pers, 1987.

Satriani, Satriani. "Pengaruh Iklim Kelas Dan Konsep Diri Terhadap Motivasi Berprestasi Dan Hasil Belajar Fisika Peserta Didik Kelas XI IPA SMA Negeri 1 Kahu." Masters, Universitas Negeri Makassar, 2016. http://eprints.unm.ac.id/3759/.

Sax, Gilbert. Principles of Educational Measurement and Evaluation. Wadsworth Publishing Company, 1973.

Slameto. Belajar Dan Faktor Yang Mempengaruhinya. Jakarta: Rineka Cipta, 2010.

Sternberg, Robert J., ed. Handbook of Creativity. 1 edition. Cambridge, U.K. ; New York: Cambridge University Press, 1998.

Syah, Muhibbin. Psikologi Pendidikan. Bandung: PT. Remaja Rosdakarya, 2011.

Thompson, Tony. "Mathematics Teachers' Interpretation of Higher-Order Thinking in Bloom's Taxonomy." International Electronic Journal of Mathematics Education 3, no. 2 (August 8, 2008): 96-109.

Utami, Munandar. Pengembangan Kreativitas Anak Berbakat. Jakarta: Rineka Cipta, 2009. 